\title{
Evaluating Allegations of Misconduct at Ford Otosan from an Internal Control Perspective ${ }^{1}$
}

\author{
Metin KILIÇ \\ orcid.org/0000-0002-5025-6384 \\ Doç. Dr., Bandırma Onyedi Eylül Üniversitesi, İİBF \\ Associate Prof., Bandirma Onyedi Eylül University, Faculty of \\ Economics and Administrative Sciences \\ metinkilic@bandirma.edu.
}

\begin{abstract}
The creation of large companies by bringing together the capital made it compulsory to form the executive staff. While the financial reports inform the stakeholders about the company's activities, the quality of financial information disclosed in these reports is ensured through independent and public audits. These audit activities give the stakeholders confidence in the usefulness of the financial statements in their decisions. Company managers create internal control systems to ensure their self-control and evaluate whether internal audit activities and business activities are carried out as they have determined. In addition, corporate governance practices that developed after many company scandals in the 2000s aimed to create a fair, transparent, accountable, and responsible management approach and structure in the management processes of companies. In addition to all these, companies apply the ethical principles they have determined to their employees and the parties they are in contact with.
\end{abstract}

\footnotetext{
${ }^{1}$ This study was presented at the 12th SCF Congress with the title of "Bir
} Otomobil Firmasındaki Yolsuzluk İddiaları Üzerine Değerlendirmeler". 
The development of information technologies enables companies to reduce the complexity of corporate management and auditing practices and allows these activities to be carried out faster. When there is a disruption in audit activities, there may be misleading financial statements, fraud, or misconduct. This study was prepared on allegations of corruption or abuse in an automotive company in the first quarter of 2021. The study examines the allegations as they are reflected in the press and evaluates them in terms of internal audit activities in line with the information disclosed.

Keywords: Misconduct, Internal Audit, Internal Control

JEL Classification: M40, M42, M48

\section{Ford Otosan'daki Suistimal İddialarının İç Kontrol Açısından Değerlendirilmesi}

\section{Öz}

Sermayenin bir araya getirilerek büyük şirketlerin kurulması, yönetici kadronun oluşturulmasını zorunlu hale getirdi. Finansal raporlar, menfaat sahiplerini şirket faaliyetleri hakkında bilgilendirmek amacıyla kullanılırken, bu tablolarda açıklanan finansal bilgilerin doğruluğu hem bağımsız denetim hem de kamu denetimi yoluyla incelenmektedir. Bu denetim faaliyetleri, paydaşlara kararlarında mali tabloların kullanılabilirliği konusunda güven verir. Şirket yöneticileri, kendi öz kontrollerini sağlamak ve iç denetim faaliyetlerinin ve iş faaliyetlerinin belirledikleri şekilde yürütülüp yürütülmediğini değerlendirmek için iç kontrol sistemleri 
oluştururlar. Ayrıca 2000'li yıllarda yaşanan birçok şirket skandalından sonra gelişen kurumsal yönetim uygulamaları, şirketlerin yönetim süreçlerinde adil, şeffaf, hesap verebilir ve sorumlu bir yönetim anlayışı ve yapısı oluşturmayı amaçlamaktadır. Tüm bunların yanı sıra şirketler belirledikleri etik ilkeleri hem kendi çalışanlarına hem de iletişimde oldukları taraflara uygulamaktadır. Bilgi teknolojilerinin gelişmesi, şirketlerin kurumsal yönetim ve denetim uygulamalarında artan karmaşıklığı azaltmalarına ve bu faaliyetlerin daha hızlı yürütülmesine olanak sağlamaktadır. Denetim faaliyetlerinde aksama olduğunda yanıltıcı mali tablolar, hile veya suiistimal olabilir. Bu çalışma, 2021 yılının ilk çeyreğinde bir otomotiv firmasında yolsuzluk veya suistimal iddiaları üzerine hazırlanmıştır. Çalışma, iddiaları basına yansıdığı şekliyle incelemekte ve açıklanan bilgiler doğrultusunda iç denetim faaliyetleri açısından değerlendirmektedir.

Keywords: Suisitimal, İç Denetim, İç Kontrol

JEL Sinıflandırması: M40, M42, M48

\section{Introduction}

Personal ambition and the desire to have more are perhaps the most essential elements of scientific development and progress. As a species that is not content with what it has and constantly wants more, human beings try to have more, sometimes by making an effort legally and sometimes by making an effort illegally. Unfortunately, it can be said that most human beings are in a structure that prefers to be happy with what they will have rather than what they have and spend their life for this purpose. Moral deficiencies, deficiencies in the legal 
structure, gaps in the control system, pressures, etc., lead people to illegal behaviors in many factors and cause them to take any action that they think can shortly reach their goals. In Turkish, there is a proverb: "The Grasshopper jumps once, takes two, gets caught in the third." This change is expressed in that the criminal will eventually be caught and receive the necessary punishment. However, the important thing is not that a criminal is caught and punished. The important thing should be to eliminate the elements or gaps that lead to crime.

The study is prepared to examine the allegations of "misconduct" in Ford Otosan and evaluate what can be done from an institutional point of view. For this purpose; This study is to examine the written notifications made in the press and company statements of the event, which started with the complaint of Ford Otosan, and which is described as corruption according to the media and misconduct according to the company, and to make evaluations in terms of internal auditing.

\section{Misconduct Concept and Types}

Misconduct is unacceptable or immoral behavior by someone in a position of authority or responsibility (https://dictionary.cambridge.org/tr). Misconduct is wrong or inappropriate behavior, especially by a professional person (https://www.collinsdictionary.com). The three types of misconduct are simple, severe, and gross. Simple misconduct may include a violation of company policy or failure to perform job duties. On the other hand, falsification of records, physical assault or threats, abuse of leave or sick time, theft of company property, etc., are examples of 
severe misconduct (https://www.industrialui.com). Gross misconduct is an act that is so serious that it justifies dismissal without notice or compensation instead of notice for a first offense. They must be acts that destroy the relationship of trust and confidence between the employer and employee, making the working relationship impossible to continue. What amounts to gross misconduct will vary from company to company, depending on the sector and the nature of the business. In general, most employers would agree that depending on the severity of the situation, the following five examples could amount to gross misconduct.

1. Theft, fraud, and dishonesty (Harassment, Bullying, Aggressive or intimidating behavior, etc.) This can incur enormous costs for employers and damage their relationship with clients or service users.

2. Offensive behavior (Harassment, Bullying, Aggressive or intimidating behavior, etc.). This can occur between colleagues, between a worker and a customer, or anyone else who comes to the worksite.

3. Breach of health and safety rules (Removing or not using machinery guards, persistently refusing to wear Personal Protective Equipment, dangerous driving on the worksite, etc.) When employees commit severe breaches of health and safety rules, this can result in reputational damage. There is also significant liability for employers.

4. Damage to property can include deliberate or willful damage to property or gross negligence that can result in substantial loss or damage to property. 
5. Serious incapacity or misconduct caused by an excess of alcohol or drugs at work (Serious incapability due to drinking or taking drugs while on duty, Possession or using drugs on the employer's premises, and Buying or selling drugs on the employer's premises.) (https://worknest.com).

\section{The Process of Misconduct at Ford Otosan}

\subsection{Detection and Process of Misconduct in Ford Otosan}

Ford Otosan is one of the important multinational companies in Turkey with a strong corporate structure. It is shown as an example due to its stature as a large company with national and international activities, its level of institutionalization, the strength of its audit and control mechanisms, and also because it considers its diverse stakeholders by operating by ethical principles and laws. In this undesirable or unexpected event, it can be said that Ford Otosan's corporate stance should be shown as an example again.

In this study, while examining the incident of misconduct, it will be acted in line with the company statements and the news in the press. Possible shortcomings and suggestions will be made to prevent such incidents. It was preferred because the event was the most critical misconduct event known in a strong company like Ford Otosan and in this sector.

Turkey became aware of the significant misconduct scandal at Ford Otosan with a notification made to the Public Disclosure Platform (KAP) on February 22. (Özpeynirci, E., 2021).

According to the press, the misconduct incident started with a denunciation. After the notification, the institution activated the 
internal audit unit to investigate the report's accuracy. After obtaining the evidence confirming the information, the extent and relevant persons were determined, and a public statement was made (https://devhaber.net).

The timeline of the event (https://www.cnnturk.com):

February 2: “S.E.E."'s computer was seized.

February 5: "E." was called to the company, interrogated'; applied to the prosecutor's office.

February 8: A lawsuit was filed against "E.", demanding the first precautionary lien of 48 million liras.

February 11: The employment contracts of "E." and "T.K." were terminated.

February 19: A precautionary lien lawsuit of 247.8 million and a debt lawsuit were filed against "E."

February 22: 247.8 million enforcement proceedings were filed against "E."

February 22: Ford Otosan reported the incident to the stock market.

According to Ford Otosan's statement, "As a result of the internal control investigation carried out in our company; the Receivables Team Leader and the employee who follows dealer receivables, have been determined to have made irregularities on dealer current accounts and the dealer limits in the direct debit system, reporting dealer receivables and risks different than they are and as a result committed an act of misconduct. Our investigation on the issue continues. 
In this respect, a criminal complaint has been filed against these persons with the charges of misappropriation; their employment contracts have been terminated immediately, and also a lawsuit has been filed for compensating TRY 247.8 million - due to receivables risk identified as of today - while reserving the right to claim further damages.

Although the receivables that are the subject of irregularities were included in our financial statements, we understand that the aged receivables tables in the footnotes of our financial statements do not reflect the current situation. The study on the final impact of these actions on our financial statements continues. We will share any material developments with our investors" (Ford Otosan 1. 2021).

\subsection{The Method of Perpetration of Misconduct in Ford}

\section{Otosan}

The essence of Ford Otosan's application to the prosecution and the lawsuits it filed is based on the claim that "Our company personnel obtained benefits by providing unfair profits to some dealers." The company alleges that "E.", an employee of 21 years, manipulated company records and electronic systems that he had access to, thanks to his job. In the petition, it was stated as follows: "The defendant caused the sale of goods to an unlimited dealer. He increased the dealer limits with fraudulent transactions. In this way, vehicles or parts were sold by misleading other units. The defendant sometimes concealed the debt of the dealer. He made it seem as if the debts of the dealers with which he had a relationship with the advance money that some dealers had invested in the company had been paid. For 
example, "O"'s limit in the bank was 1 million liras, and he recorded it as 30 million. Another company whose debt has been rendered invisible is "Ş Automotive" 21 million 643 thousand 462 of this company in 2017, 45 million 531 thousand 293 in 2018, 81 million 27 thousand 428 TL in 2019, 38 million 611 TL in 2020. It was shown as if the debt of 1 thousand 406 liras had been paid." (https:www.cnnturk.com), (https://tr.sputniknews.com/). It is claimed that misconduct is an organized event involving 7-8 employees and 1415 dealers. According to these claims (www.seskocaeli.com);

Automotive companies establish dealer networks for vehicle sales. Entrepreneurs are included in the franchise system and can become dealers in return for specific conditions and guarantees. The automotive company sells the vehicle to the dealer with a specified payment term. In Ford Otosan's system, the average time for receivables from dealers is approximately 25 days. Like other companies with a widespread dealer organization, Ford Otosan also has a Direct Collection System. According to this system, a credit limit is allocated to the dealer through contracted banks.

Banks deposit the money into Ford Otosan's account near the payment due date. Thus, Ford Otosan can automatically collect its receivables from the dealer. The chain of events that form the basis of this research starts here; The company's person responsible for dealer receivables and the employee who monitors the collections conspire and set up a factoring company in their name.

Dealers make transactions through this factoring company when they buy a vehicle. Therefore, he invests the money in the factoring firm. Although the average payment term is 25 days in the 
system with Ford Otosan's own contracted banks, this period is extended to 4-5 months for transactions made through the factoring company. Employees of the company, who follow the receivables of the dealers in the business, played with these times. The Direct Collection System is rendered ineffective, as money is exchanged and exchanged through the factoring company. It is thought that they have been dealing with Ford Otosan in this way for about four years. Thus, while the dealer's receivables are postponed or reduced, Ford Otosan is harmed, the dealers profit and those who do this work receive payment from the dealers.

\subsection{The Parties of the Abuse in Ford Otosan, its Financial} Dimension and The Continuation of the Process

According to the information regarding the case, "S.E.E." is the head of misconduct. "E" is a name that joined the company on October 11, 1999. In April 2004, he became the 'Receivables Team Leader.' The unit headed by " $\mathrm{E}$ " is responsible for the follow-up of the receivables from the company's 100 dealers. Like "E," and his wife, "D.E," who worked at Ford Otosan for a while, is also named as a 'suspect' in the prosecution file. "T.K.," who has been fired, is accused of deleting several files from the records while the auditors were investigating (https://kronos34.news). It explains that six dealers were involved in this incident, and the share of these dealers in total sales was 3\%. (Özpeynirci, E., 2020), (Ford Otosan 2. 2021).

Ford Otosan reviewed its business relations with the dealers involved in the fraud and decided that they would be terminated within a specific plan, considering their acceptance, payment, and 
legal cooperation with Ford Otosan. Ford Otosan activities and customer services will continue without any disruption through the loss of turnover from sales to the said dealers, as other dealers operating in the same regions and new dealerships to be created would take over.

In publicly disclosed financial statements on 6 August 2021, Ford Otosan announced that 323 million TL had been reserved for doubtful receivables. Approximately 225 Million TL of the said receivables consists of the receivables from the dealers who refused to pay, and it was decided that claims would be filed against these dealers. Additional lawsuits may be filed depending on the against other dealers for which provision for doubtful receivables has been set aside by Ford Otosan, depending on non-payment.

Ford Otosan stated that investors would be notified of significant developments with important consequences regarding the current and possible litigation (Ford Otosan 2. 2021).

\section{Evaluation of The Event in Terms of Internal Audit}

\section{Activities}

Ford Otosan is one of the leading companies in Turkey that carries out rooted and most advanced applications. It can be said that it operates according to corporate governance principles with a professional management approach and has a solid corporate structure. To assist management inFord Otosan, there are committees such as the corporate governance committee, the early detection and management of risk committee, the audit committee, and the compensation committee (Ford Otosan 3. 2021), and these committees 
are reported to be working actively (Ford Otosan 4. 2021). Ford Otosan regularly undergoes independent audits and operates in the internal audit unit (Ford Otosan 5. 2021).

The case of misconduct that took place within this structure can be evaluated in terms of internal auditing as follows;

The internal control system in enterprises; operates to increase efficiency and productivity in activities, ensuring compliance with laws and external and internal regulations, ensuring that business assets are secure, ensuring the reliability of financial reporting, and increasing corporate governance compliance (Selimoğlu, S.; Uzay, Ş., 2014). The internal control system will contribute to the achievement of the existence of the enterprises with preventive, detective, corrective, and directive controls against the risks that will prevent the achievement of the objectives determined by the business management. For this reason, there is a strong relationship between the effective operation of the internal control system and the achievement of the objectives set by the business management. With this point of view, Ford Otosan explains its structuring as follows:

"In addition to following policies, procedures, and instructions included in process flow as key parts of the internal control system, Ford Otosan also applies an internal control plan annually which covers all Company operations. With this structure, 2,215 control points are being tested as an assurance to the Board of Directors and shareholders related to the accuracy of the Company's operations. The Audit Committee periodically monitors internal control and internal audit activities, reviews and approves annual audit plans as a subcommittee of the Board of Directors. The Audit Committee 
provides opinions on the financial reports for the approval of the Board of Directors and provides recommendations to the Board where required. Koc Holding, Ford Motor Company, and Ford Otosan Internal Control Department perform regular audits in the company annually. Ford Otosan's authorized dealers and services are also audited for their transactions with Ford Otosan periodically by the dealer audit function of the Internal Control Department. All denunciations and complaints about Ford Otosan related operations are reviewed, investigated, and finalized by the Internal Control Department. All control issues identified during the internal control, internal audit, or external audit processes are evaluated, corrective actions are planned and tracked for implementation to improve internal control systems by the Internal Control Department. Results of these reports are presented to the Audit Committee regularly, which consists of the independent Board members." (Ford Otosan 5. 2021). The misconduct event that took place shows gaps in the current system of the Ford Otosan. Ford Otosan needs to identify the holes in the internal control system and implement the necessary control measures and methods so that this or similar incidents do not occur again.

Ford Otosan must establish different controls to prevent a business from being managed continuously by one or more people from start to finish.

The effectiveness of the functioning of the internal control system is primarily evaluated by the internal audit units and audit committees in the enterprises. The existence of teams that assess the effectiveness of the internal control system adds strength to the enterprises. However, in this case, it cannot be said that the units that 
evaluate the effectiveness of the internal control units are compelling enough. For this reason, changes and innovations such as renewing or changing the structure of the internal audit unit may be required.

Fraud, misconduct, or corruption is often perpetrated by business employees who want to take advantage of pressure, attitudes, or opportunities. For this reason, a mechanism should be established to carefully evaluate the abnormal changes in the assets and social life of the people in critical positions.

Communications of people in influential positions with the same customers or vendors may become personal over time. This personalization may cause negative situations for the business. Therefore, rotation among employees may be required, a change in different positions may be needed instead of working continuously in a particular place.

\section{Conclusion}

This case of abuse, which emerged within the corporate structure of Ford Otosan, shows that malicious people can always take advantage of the gaps in an institution where the internal control system is active and internal audit activities are carried out continuously and turn to unofficial ways. It is always desirable that such an event does not occur. However, the reaction to this undesirable event or similar events is just as important. In this incident, Ford Otosan initiated the legal process by making the necessary investigations, took the allegations to court, started the collection process for the people and institutions involved in the misconduct, terminated the business relations, and revealed its corporate stance. 
All necessary information was shared with the stakeholders on a day-to-day basis. It is agreed that Ford Otosan will never condone such misconduct. This incident at Ford Otosan is essential in guiding and setting an example for other companies that encounter such problems. When the litigation process is over, and the court determines the outcome of the allegations, this process will be revealed in more detail, and different evaluations and inferences will be made from a broader perspective.

\section{References}

CNNTURK, (2021). “Ford Otomotiv'de Yolsuzluk İddiası: Adım Adım 248 Milyonluk Yolsuzluğun Şifreleri", https://www.cnnturk.com/turkiye/ford-otomotivde-yolsuzluk-iddiasi -adim-adim-248-milyonluk-yolsuzlugun-sifreleri),

Ford Otosan 1. (2021). https://www.fordotosan.com.tr/tr/yatiri mcilar/duyurular?page $=2$

Ford Otosan 2 (2021). https://www.fordotosan.com.tr/tr/yatiri mcilar/duyurular/ozel-durum-aciklamalari

Ford Otosan 3. (2021). https://www.fordotosan.com.tr/en/in vestors/corporategovernance/bo ard-committees

Ford Otosan 4. (2021). https://www.fordotosan.com.tr/tr/yatiri mcilar/finansal-raporlar/faaliyet-raporlari

Ford Otosan 5. (2021). https://www.fordotosan.com.tr/en/in vestors/financial-statements/annual-reports

https://devhaber.net/ford-otosandaki-248-milyonluk-yolsuzlu k-nasil-basladi-suclamalar-ne-1310/ 13 Nisan 2021 
https://dictionary.cambridge.org/tr/s\%C3\%B6zl\%C3\%BCk/ing ilizce/misconduct),

https://www.collinsdictionary.com/dictionary/english/accusati on-of-misconduct

https://www.industrialui.com/three-types-of-misconduct/

Kronos (2021). “Koç'u Sarsan Skandal: Yolsuzluğa Karışan Bayilerde Mahkemeye Verildi" https://kronos34.news/tr/kocu-sarsanskandal-323-milyon-tllik-yolsuzluga-karisan-bayiler-de-mahkemeyeverildi/)

Özpeynirci, E. (2021). “Tarihimizin En Büyük Otomobil Yolsuzluğu, https://www.bursadabugun.com/yazarlar/emre-ozpeynir ci-120/tarihimizin-en-buyuk-otomobil-yolsuzlugu-29260.html.

12.08.2021.

Selimoğlu, S., \& Uzay, Ş., (2014). Muhasebe Denetimi, Ankara: Gazi Kitapevi.

SesKoçaeliç (2021) “Ford'ta 248 Milyonluk Vurgun Nasıl Yapıldı?" https:/www.seskocaeli.com/haber/6532626/fordta-248milyonluk-vurgun-nasil-yapildi

Spuntnic, (2021). Ford Otomotivde 248 Milyon Liralık Yolsuzluk İddiası: Suçlamalar Ne?" https://tr.sputniknews.com/ 20210413/ford-otomotivde-248-milyon-liralik-yolsuzluk-iddiasisuclamalar-ne-1044259833.html.

Worknest, Gross Misconduct: 5 examples every employer should know", https://worknest.com/blog/5-examples-gross-miscon duct/ 